\title{
Maxillofacial Fractures: Etiology, Pattern of Presentation, and Treatment in University of Port Harcourt Teaching Hospital, Port Harcourt, Nigeria
}

\author{
S. E. Udeabor, B. O. Akinbami, K. S. Yarhere, and A. E. Obiechina \\ Department of Oral and Maxillofacial Surgery, College of Health Sciences, University of Port Harcourt, East-West Road, \\ Choba 500272, Port Harcourt, Nigeria
}

Correspondence should be addressed to S. E. Udeabor; samudeabor@yahoo.com

Received 22 July 2014; Revised 20 October 2014; Accepted 23 October 2014; Published 6 November 2014

Academic Editor: Dennis Flanagan

Copyright (C) 2014 S. E. Udeabor et al. This is an open access article distributed under the Creative Commons Attribution License, which permits unrestricted use, distribution, and reproduction in any medium, provided the original work is properly cited.

\begin{abstract}
Objective. To retrospectively analyze the pattern of presentation and modalities of management of maxillofacial fractures in our center. Methods. The medical records of all the patients who sustained maxillofacial fractures presenting to a major referral hospital in Niger Delta region of Nigeria were retrieved and reviewed. The data collected was analyzed using SPSS statistical package. Results. Eighty-six patients presented with 135 maxillofacial fractures during the period under review. A male to female ration of 3:1 was recorded and patients in their third decade of life were mostly affected (46.5\%). Road traffic accident (RTA) was the commonest etiology accounting for $46.5 \%$ whereas assault was second (19.8\%). The mandible was the most frequently fractured bone $(59.3 \%)$ followed by the zygoma (18.5\%). The main stay of treatment was closed reduction with IMF (40.4\%). Conclusion. Treatment modalities for maxillofacial fractures in our center have not witnessed any significant changes. Effort should be made to ensure the availability of miniplates to ensure adequate treatment for all categories of our patients.
\end{abstract}

\section{Introduction}

Maxillofacial injuries in general occur quite commonly following trauma and these injuries if not properly managed can negatively influence both the psychosocial and functional activities of the patient [1]. This is as a result of the centrality of the facial region as a key factor in human identity, esthetics, and general well-being $[1,2]$. These injuries can affect both skeletal and soft tissue structures of the facial region $[3,4]$ and often times, based on the etiology and mechanism of injury, occur in association with other systemic injuries thereby requiring multidisciplinary approach for their management [4-7].

The etiologies of maxillofacial fractures vary from one geographical location to another and also among different age groups. Road traffic accident (RTA) has been severally reported as the leading etiology of maxillofacial fractures especially in the developing world including Nigeria, whereas assault leads the pack of etiologies in the developed world [8-11]. However, there is an increasing influence of assault in our environment due to the current wave of terrorism and gun violence. Young men in the second and third decades of life are the worst afflicted owing to the fact that they engage frequently in activities that can predispose them to trauma [9, $10,12]$. Apart from RTA and assaults, other common causes of maxillofacial fractures include sporting injuries, industrial accidents, domestic accidents, falls, and animal bites [13].

The age-long principle of fracture management; reduction and immobilization also applies to maxillofacial fractures; however, the pathway to achieving this principle is influenced by many other factors. It should be noted that the treatment outcome of maxillofacial fractures is mainly dependent among other things on the degree of injury, type of fracture, the expertise of the surgeon, and available technology $[1,2]$. Over the years, the epidemiology of maxillofacial fractures keeps changing and new trends in etiology, pattern of presentation, and management are constantly evolving. This therefore necessitates a constant appraisal of these injuries in order to keep abreast with recent developments and the changing pattern of their management. This report 
TABLE 1: Gender Distribution and Etiology of Maxillofacial Fractures.

\begin{tabular}{|c|c|c|c|c|c|c|c|c|c|}
\hline \multirow[b]{2}{*}{ Gender } & \multicolumn{8}{|c|}{ Etiology } & \multirow[b]{2}{*}{ Total (\%) } \\
\hline & $\begin{array}{c}\text { RTA (MV) } \\
(\%)\end{array}$ & $\begin{array}{c}\text { RTA (MB) } \\
(\%)\end{array}$ & Gunshot (\%) & $\begin{array}{c}\text { Industrial } \\
(\%)\end{array}$ & Assault (\%) & $\begin{array}{c}\text { Boat } \\
\text { Accident (\%) }\end{array}$ & $\begin{array}{c}\text { Animal } \\
\text { Attack (\%) }\end{array}$ & $\begin{array}{c}\text { Missing Data } \\
(\%)\end{array}$ & \\
\hline Male & $12(14.0)$ & $16(18.6)$ & $9(10.5)$ & $2(2.3)$ & $6(7.0)$ & $2(2.3)$ & $0(0.0)$ & $18(20.9)$ & $65(75.6)$ \\
\hline Female & 10 (11.6) & $2(2.3)$ & $2(2.3)$ & $1(1.2)$ & $0(0.0)$ & $0(0.0)$ & $1(1.2)$ & $6(7.0)$ & $21(24.4)$ \\
\hline Total & $22(25.6)$ & $18(20.9)$ & $11(12.8)$ & $3(3.5)$ & $6(7.0)$ & $2(2.3)$ & $1(1.2)$ & $23(26.7)$ & $86(100)$ \\
\hline
\end{tabular}

MV: Motor Vehicle; MB: Motorbike; $P$-value: 0.001 .

TABLE 2: Etiology of Maxillofacial Fractures According to Age Groups.

\begin{tabular}{|c|c|c|c|c|c|c|c|c|c|}
\hline \multirow{2}{*}{$\begin{array}{l}\text { Age Group } \\
\text { (Years) }\end{array}$} & \multirow[b]{2}{*}{$\begin{array}{c}\text { RTA (MV) } \\
(\%)\end{array}$} & \multirow[b]{2}{*}{$\begin{array}{c}\text { RTA (MB) } \\
(\%)\end{array}$} & \multirow[b]{2}{*}{ Gunshot (\%) } & \multicolumn{2}{|c|}{ Etiology } & \multirow[b]{2}{*}{$\begin{array}{c}\text { Boat } \\
\text { Accident (\%) }\end{array}$} & \multirow[b]{2}{*}{$\begin{array}{c}\text { Animal } \\
\text { Attack (\%) }\end{array}$} & \multirow[b]{2}{*}{$\begin{array}{c}\text { Missing Data } \\
(\%)\end{array}$} & \multirow[b]{2}{*}{ Total (\%) } \\
\hline & & & & $\begin{array}{c}\text { Industrial } \\
(\%)\end{array}$ & Assault (\%) & & & & \\
\hline $0-10$ & $0(0.0)$ & $0(0.0)$ & $1(1.2)$ & $0(0.0)$ & $0(0.0)$ & $0(0.0)$ & $1(1.2)$ & $0(0.0)$ & $2(2.3)$ \\
\hline $11-20$ & $1(1.2)$ & $4(4.7)$ & $2(2.3)$ & $0(0.0)$ & $0(0.0)$ & $0(0.0)$ & $0(0.0)$ & $4(4.7)$ & $11(12.8)$ \\
\hline $21-30$ & $15(17.4)$ & $9(10.5)$ & $5(5.8)$ & $0(0.0)$ & $1(1.2)$ & $1(1.2)$ & $0(0.0)$ & $12(14.0)$ & $43(50.0)$ \\
\hline $31-40$ & $2(2.3)$ & $4(4.7)$ & $3(3.5)$ & $2(2.3)$ & $3(2.3)$ & $1(1.2)$ & $0(0.0)$ & $4(4.7)$ & $19(22.1)$ \\
\hline $41-50$ & $2(2.3)$ & $1(1.2)$ & $0(0.0)$ & $1(1.2)$ & $1(1.2)$ & $0(0.0)$ & $0(0.0)$ & $1(1.2)$ & $6(7.0)$ \\
\hline $51-60$ & $2(2.3)$ & $0(0.0)$ & $0(0.0)$ & $0(0.0)$ & $0(0.0)$ & $0(0.0)$ & $0(0.0)$ & $1(1.2)$ & $3(3.5)$ \\
\hline $61-70$ & $0(0.0)$ & $0(0.0)$ & $0(0.0)$ & $0(0.0)$ & $0(0.0)$ & $0(0.0)$ & $0(0.0)$ & $1(1.2)$ & $1(1.2)$ \\
\hline $\begin{array}{l}71 \text { and } \\
\text { Above }\end{array}$ & $0(0.0)$ & $0(0.0)$ & $0(0.0)$ & $0(0.0)$ & $1(1.2)$ & $0(0.0)$ & $0(0.0)$ & $0(0.0)$ & $1(1.2)$ \\
\hline Total (\%) & $22(25.6)$ & $18(21.0)$ & $11(12.8)$ & $3(3.5)$ & $6(7.0)$ & $2(2.3)$ & $1(1.2)$ & $23(26.7)$ & $86(100)$ \\
\hline
\end{tabular}

MV: Motor Vehicle; MB: Motorbike; $P$-value: 0.000 .

therefore is a retrospective analysis of the etiology, pattern, and modalities of management of maxillofacial fractures in our center.

\section{Patients and Methods}

The medical records of all the trauma patients that presented to the department of Oral and Maxillofacial Surgery, University of Port Harcourt Teaching Hospital, between 2007 and 2013 (6 years) were retrospectively reviewed. The variables obtained include patient's age, gender, mechanism of injury/etiology, type of maxillofacial fracture sustained, site of fracture, and treatment given. The mandibular fractures were broadly categorized into fractures of the condyle, ramus, angle, body, parasymphysis, symphysis, and lower alveolar bones.

Midfacial fractures were also classified into maxillary (Le Fort I, II, III, and IV) fractures, zygomatic complex fractures, orbital fractures, upper alveolar bone fractures, and nasoorbitoethmoidal (NOE) fractures. Fractures involving the frontal region were also documented and when a patient sustained multiple fractures in the upper, middle, and lower facial skeletons, they were recorded as panfacial fractures. The various methods of treatment and reasons for treatment choice as well as any modification were documented.

Analysis of the data was done using SPSS version 16 and results were presented. Frequency distribution of variables were generated and measures of central tendency were calculated to summarize the numerical data. Student's $t$-test and ANOVA were used for continuous variables while Chisquare test was used for categorical variables and $P$ values $<$ 0.05 were considered as statistically significant.

\section{Results}

A total number of 86 patients sustained 135 maxillofacial fractures during the period under review. Males were 65 (75.6\%) and females were $21(24.4 \%)$ with a male to female ratio of $3: 1$ (Table 1). A significant male preponderance was observed among the different age groups and for the various etiologies (Table 2). Patients' ages ranged from 4 years to 76 years with those in the third and fourth decades of life mostly affected (46.5\% and 22.1\%, resp. (Table 2)). Road traffic accident (RTA) was the commonest cause of maxillofacial fractures accounting for 46.5\%; assault was second (19.8\%), whereas animal attack was the least among the causes $(1.2 \%)$ (Table 1).

A total of 80 (59.3\%) mandibular fractures were recorded, making it the most frequently fractured bone of the maxillofacial skeleton. This was followed by zygomatic complex fractures $25(18.5 \%)$ and maxillary fractures 19 (14.1\%). In the mandible, the body had the highest number of fractures as opposed to the ramus, which was the least fractured site (Table 3).

Thirty-eight patients (40.4\%) had their fractures treated by closed reduction and intermaxillary fixation (IMF) making it the commonest modality of treatment for maxillofacial fractures in our center (Table 4). 
TABLE 3: Maxillofacial fracture pattern.

\begin{tabular}{lccc}
\hline Hard tissue & Type of fracture & Frequency & Percentage (\%) \\
\hline \multirow{4}{*}{ Mandible } & Condylar & 5 & 3.7 \\
& Body & 32 & 23.7 \\
& Parasymphysis & 19 & 14.1 \\
& Symphysis & 3 & 2.2 \\
& Ramus & 2 & 1.5 \\
& Angle & 13 & 9.6 \\
& Dento-alveolar & 6 & 4.4 \\
Maxilla & Le Fort I & 5 & 3.7 \\
& Le Fort II & 5 & 3.7 \\
& Le Fort III & 1 & 0.7 \\
Zygomatic & Le Fort IV & 1 & 0.7 \\
complex & Palatal split & 1 & 0.7 \\
Orbital & Dento-alveolar & 6 & 4.4 \\
Zaso-orbito- & ZC fracture & 25 & 18.5 \\
ethmoidal & Orbital Rim & 1 & 0.7 \\
complex & Blow-out & 3 & 2.2 \\
Nasal & NOE fractures & 4 & 3.0 \\
Frontal bone & Nasal fractures & 1 & 0.7 \\
Total & & 2 & 100 \\
\hline
\end{tabular}

TABLE 4: Treatment modalities for maxillofacial fractures.

\begin{tabular}{lcc}
\hline Treatment given & Frequency & Percentage (\%) \\
\hline Conservative & 3 & 3.2 \\
Debridement + Soft tissue repair & 12 & 12.8 \\
ORIF + IMF & 29 & 30.9 \\
Closed red + IMF & 38 & 40.4 \\
Closed red + Suspension & 4 & 4.3 \\
Splinting & 8 & 8.5 \\
\hline Total & 94 & 100 \\
\hline
\end{tabular}

\section{Discussion}

Fractures of the facial skeleton are commonplace following trauma and therefore form a major part of the overall duty of an Oral and Maxillofacial Surgeon [10, 14]. These fractures occur commonest in young adults especially males in third and fourth decades of life because they are majorly involved in many outdoor activities and reckless driving $[5,9,10,12]$. This assertion is supported by our study in which more than $75 \%$ of the study populations were males and $68.6 \%$ were between the ages of 20 to 40 years.

Road traffic accidents (RTA) were by far the leading cause of maxillofacial fractures from our study accounting for $46.5 \%$ of the total. This is in keeping with results from other studies, which reported RTA as the leading cause of maxillofacial fractures especially in the developing world including Nigeria. Assault, on the other hand, is reported as the most frequent cause of maxillofacial fractures in the developed world [8-11]. The reasons for this high rate of RTA in Nigeria include poor road networks, improper licensing of drivers/riders, nonusage of seat belts, neglect of helmets by motorbike riders, and noncompliance with traffic rules among others $[4,5,9,10,13]$.

An earlier report in the last decade on maxillofacial fractures from another center in Port Harcourt showed assault/violence to be the leading cause of maxillofacial fractures in the region and the author adduced this to youth restiveness and excessive use of firearms [15]. The period of that report in question actually coincided with the peak of militancy in the Niger Delta region as a whole [16]. However, with the amnesty program of the federal government [16], there seems to be a reduction in assault/violence in the region as is evident from this present study.

Despite this improvement, assault/violence in the form of terrorism is significantly on the increase in the country especially in the northern region. This might eventually turn out in the near future to be the most significant etiological factor of maxillofacial fractures in our nation if the current wave of terrorism and gun violence is not checked.

Based on the high prevalence of RTA emanating from motorbikes as is obvious from this study and other previous reports $[10,13]$, various state governments in Nigeria have banned their use for transportation especially in the major cities. This obviously will go a long way in reducing the rate of motorbike-related accidents. However, alternative means of transportation and mass transit like the rail system should be adequately developed to cater for the transportation needs of the teeming populace.

Mandibular fracture was the highest occurring fractures from this review accounting for $59.2 \%$ of the total fractures. This is in agreement with other reports from across Nigeria $[10,17]$ but differs from studies from the western world where nasal bone fractures [5] and zygomatic complex fractures [18] occur more frequently. The main fracture site in the mandible is the body, which accounted for $40 \%$ of the total mandibular fractures from the present study. This result agrees with worldwide literature $[5,10,17]$. In the middle third, the zygoma is the most involved site due to its projection and multiple articulations with other facial skeletons making it very vulnerable to fractures on impact $[4,18]$.

The place of open reduction and internal fixation (ORIF) with miniplate osteosynthesis in the surgical management of maxillofacial fractures cannot be overemphasized as it promises a shortened period of intermaxillary fixation (IMF), bony union with minimal callus formation, rapid recovery of normal jaw functions, and maintenance of normal body weights among others [14]. Despite these advantages, its use in our center is still a bit limited mainly due to cost and the time required to procure the plates.

The inefficiency of the Nigerian national health insurance scheme means that patients still have to directly pay for their treatments and only a few of our patients can afford the use of miniplate osteosynthesis for their fracture management. Therefore, most of our patients were treated by nonrigid osteosynthesis (transosseous wiring) or closed reduction with a long period of IMF (6 weeks). This is virtually the situation 
with other maxillofacial surgical centers in other parts of the country [17, 19-21]. Nevertheless, the documented outcome of treatment with the use of closed reduction and nonrigid fixation from various centers across Nigeria is comparable with treatment outcomes of ORIF with miniplates to a very large extent [19-21].

To achieve reduction of malunited fractured segments of the mandible, we often do not raise mucoperiosteum prior to IMF; we generally maneuver flat small sized osteotome via the gingival sulcus into the fracture sites to separate the bony segments, and the refracturing processes are completed with the use of mallets. Quite often, we treat zygomatic bone fractures affecting one suture with closed reduction via the Gillie's temporal approach without the need for fixation. Fixation becomes necessary however in cases that presented late or comminuted and unstable fractures of the zygomatic complex. Also, where plates could not be afforded, we achieved fixation of Le Fort fractures with internal suspensions.

The major limitation of the present study is in its retrospective design, mainly due to poor record keeping and insufficient data from the available patients' records. The paucity of data may therefore influence the pattern of occurrence of maxillofacial fractures in our environment. Therefore, a larger data based prospective study may help to improve upon our present findings and also discover subsequent changes in the trend and pattern of these fractures.

\section{Conclusion}

From our study, we found out that up till now, RTA still remains the leading cause of maxillofacial fractures in our environment and this is closely followed by assault especially among men in their productive years. Even though miniplate osteosynthesis is now the mainstay of fracture management across the surgical world, a higher proportion of our patients were treated by the traditional method of closed reduction and IMF. There is therefore a need for our government to enforce the health insurance scheme and ensure a good and secure environment for the marketing, distribution, and availability of bone plates. It is also recommended that these miniplates manufactured for low-income countries like ours be subsidized so that all categories of our patients will benefit from their usage.

\section{Conflict of Interests}

The authors declare that there is no conflict of interests regarding the publication of this paper.

\section{References}

[1] K. Yamamoto, Y. Matsusue, S. Horita, K. Murakami, T. Sugiura, and T. Kirita, "Clinical analysis of midfacial fractures," Materia Socio Medica, vol. 26, no. 1, pp. 21-25, 2014.

[2] A. Parashar and R. K. Sharma, "Unfavourable outcomes in maxillofacial injuries: how to avoid and manage," Indian Journal of Plastic Surgery, vol. 46, no. 2, pp. 221-234, 2013.
[3] A. O. Fasola, A. E. Obiechina, and J. T. Arotiba, "Soft tissue injuries of the face: a 10 year review," African Journal of Medicine and Medical Sciences, vol. 29, no. 1, pp. 59-62, 2000.

[4] S. Udeabor, V. I. Akinmoladum, A. E. Obiechina, and A. A. Olusanya, "Pattern of midface trauma with associated concomitant injuries in a Nigerian referral centre," Nigerian Journal of Surgery, vol. 20, no. 1, pp. 26-29, 2014.

[5] E. D. Arslan, A. G. Solakoglu, E. Komut et al., "Assessment of maxillofacial trauma in emergency department," World Journal of Emergency Surgery, vol. 9, no. 1, article 13, 2014.

[6] S. Yamano, M. Nissenbaum, T. B. Dodson, G. O. Gallucci, and C. Sukotjo, "Multidisciplinary treatment for a young patient with severe maxillofacial trauma from a snowmobile accident: a case report," The Journal of Oral Implantology, vol. 36, no. 2, pp. 141$144,2010$.

[7] J. H.-J. Fong, H.-T. Wu, Y.-W. Chio et al., "Comprehensive rehabilitation after severe maxillofacial injury in a cleft patient," Journal of the Chinese Medical Association, vol. 73, no. 10, pp. 543-548, 2010.

[8] R. Bali, P. Sharma, A. Garg, and G. Dhillon, "A comprehensive study on maxillofacial trauma conducted in Yamunanagar, India," Journal of injury \& violence research, vol. 5, no. 2, pp. 108116, 2013.

[9] A. O. Fasola, E. A. Nyako, A. E. Obiechina, and J. T. Arotiba, "Trends in the characteristics of maxillofacial fractures in Nigeria," Journal of Oral and Maxillofacial Surgery, vol. 61, no. 10, pp. 1140-1143, 2003.

[10] W. L. Adeyemo, A. L. Ladeinde, M. O. Ogunlewe, and O. James, "Trends and characteristics of oral and maxillofacial injuries in Nigeria: a review of the literature," Head \& Face Medicine, vol. 1 , article 7, 2005.

[11] R. Gassner, T. Tuli, O. Hächl, A. Rudisch, and H. Ulmer, "Cranio-maxillofacial trauma: a 10 year review of 9543 cases with 21067 injuries," Journal of Cranio-Maxillofacial Surgery, vol. 31, no. 1, pp. 51-61, 2003.

[12] B. van den Bergh, K. H. Karagozoglu, M. W. Heymans, and T. Forouzanfar, "Aetiology and incidence of maxillofacial trauma in Amsterdam: a retrospective analysis of 579 patients," Journal of Cranio-Maxillofacial Surgery, vol. 40, no. 6, pp. e165-e169, 2012.

[13] S. E. Udeabor, V. I. Akinmoladun, O. A. Fasola, and A. E. Obiechina, "Trends in the aetiology of middle third facial injuries in southwest Nigeria," Oral Surgery, vol. 5, no. 1, pp. 7$12,2012$.

[14] I. Abbas and K. Ali, "Management of mandibular fractures-a prospective study," Pakistan Oral \& Dental Journal, vol. 22, no. 2, pp. 151-152, 2002.

[15] E. T. Adebayo, "Maxillofacial fractures in Port Harcourt, Nigeria-a short report," African Journal of Trauma, vol. 2, pp. 85-87, 2004.

[16] O. Oluduro and O. F. Oluduro, "Nigeria: in search of sustainable peace in the Niger delta through the amnesty programme," Journal of Sustainable Development, vol. 5, no. 7, pp. 48-61, 2012.

[17] E. T. Adebayo, O. S. Ajike, and E. O. Adekeye, "Analysis of the pattern of maxillofacial fractures in Kaduna, Nigeria," British Journal of Oral and Maxillofacial Surgery, vol. 41, no. 6, pp. 396400, 2003.

[18] A. Dibaie, S. Raissian, and S. Ghafarzadeh, "Evaluation of maxillofacial traumatic injuries of forensic medical center of ahwaz, Iran, in 2005," Pakistan Journal of Medical Sciences, vol. 25, no. 1, pp. 79-82, 2009. 
[19] O. K. Ogundipe, A. O. Afolabi, and O. Adebayo, "Maxillofacial fractures in Owo, South Western Nigeria. A 4-year retrospective review of pattern and treatment outcome," Dentistry, vol. 2, p. 132, 2012.

[20] V. I. Ugboko, S. A. Odusanya, and O. O. Fagade, "Maxillofacial fractures in a semi-urban Nigerian teaching hospital: a review of 442 cases," International Journal of Oral and Maxillofacial Surgery, vol. 27, no. 4, pp. 286-289, 1998.

[21] A. O. Fasola, A. E. Obiechina, and J. T. Arotiba, "An audit of midfacial fractures in Ibadan, Nigeria," African Journal of Medicine and Medical Sciences, vol. 30, no. 3, pp. 183-186, 2001. 


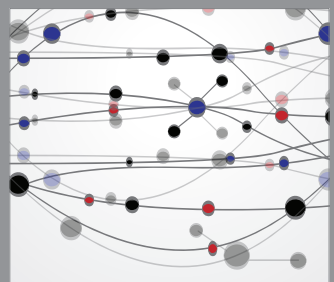

The Scientific World Journal
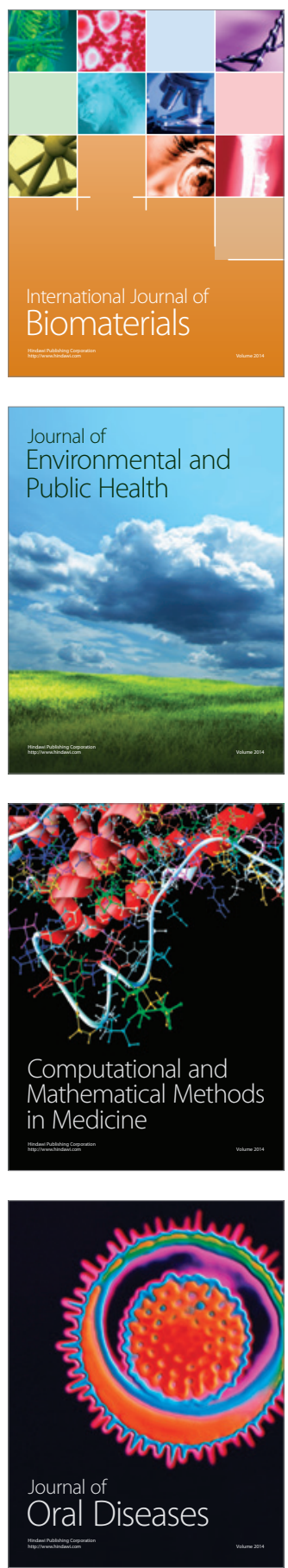
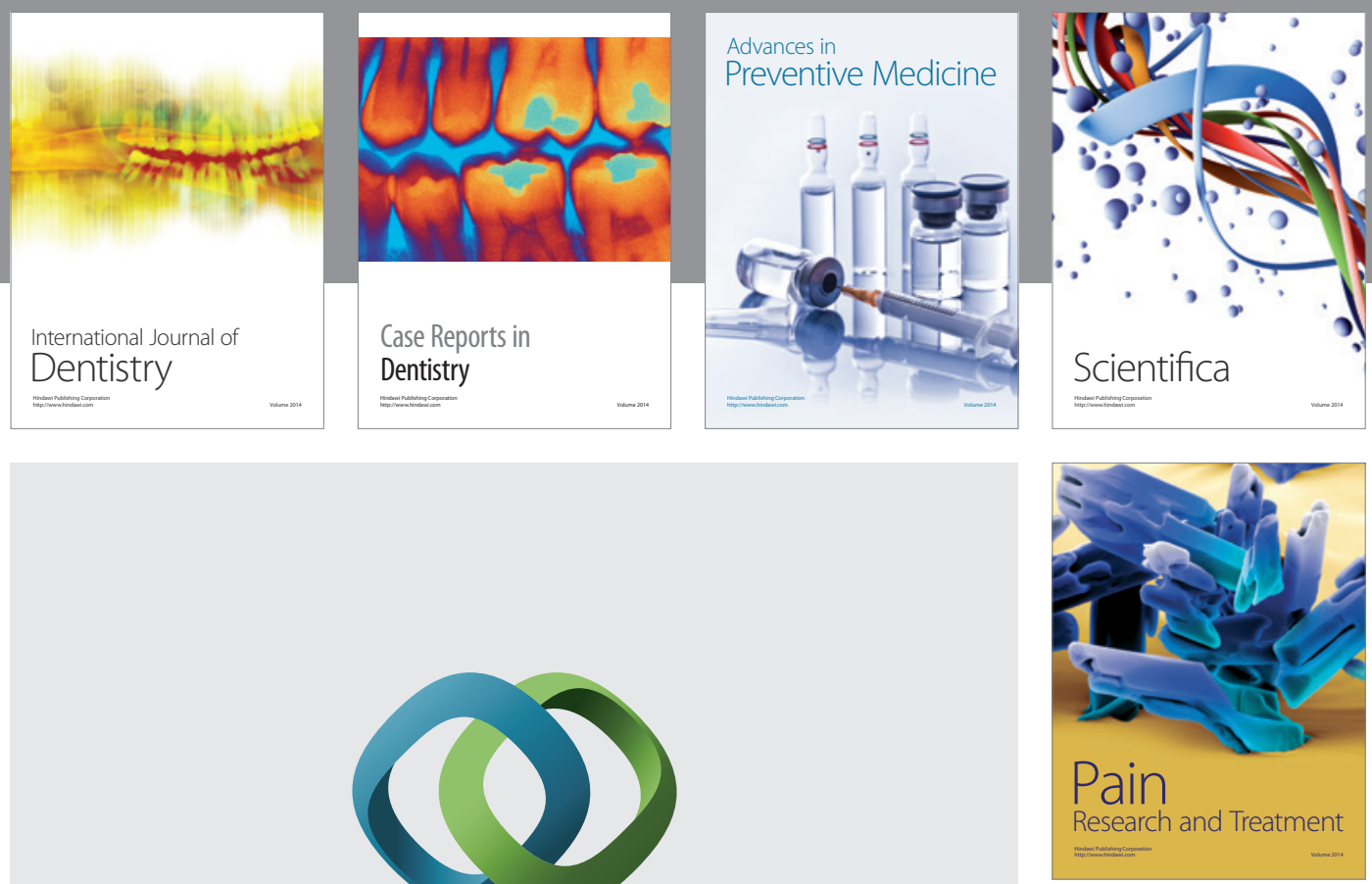

\section{Hindawi}

Submit your manuscripts at

http://www.hindawi.com
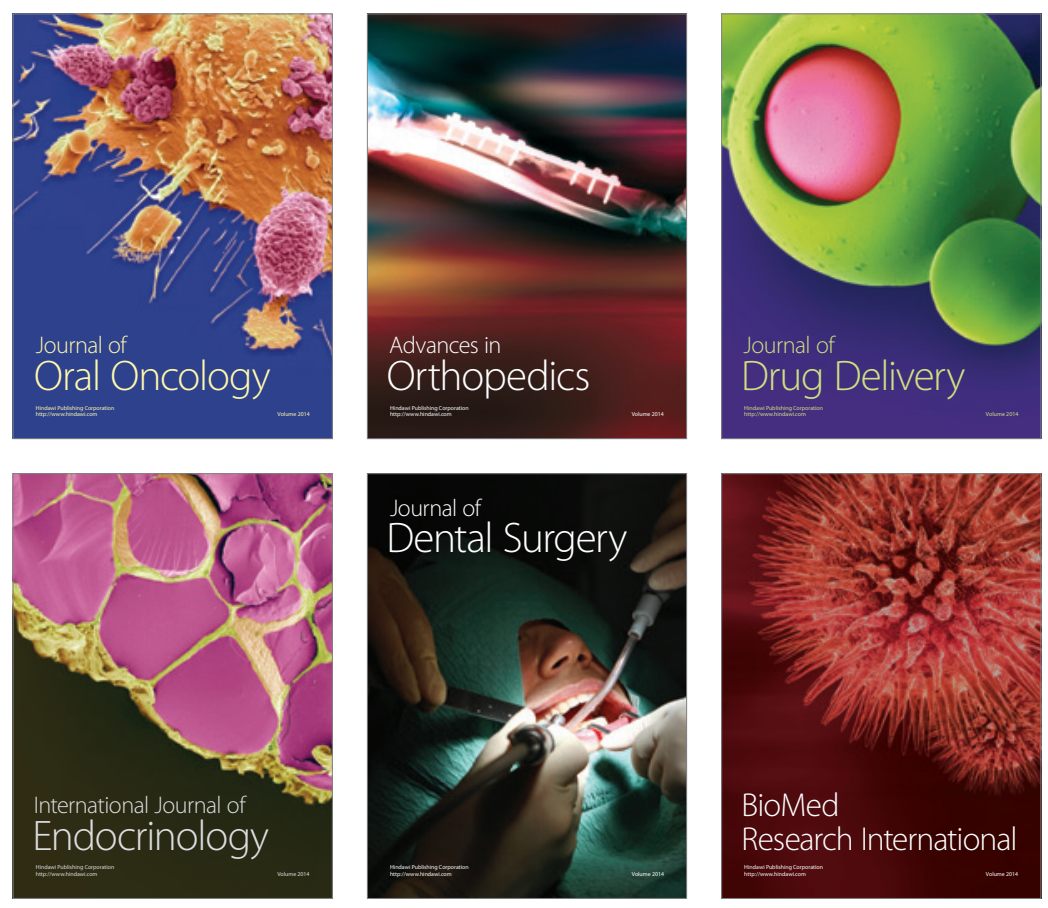

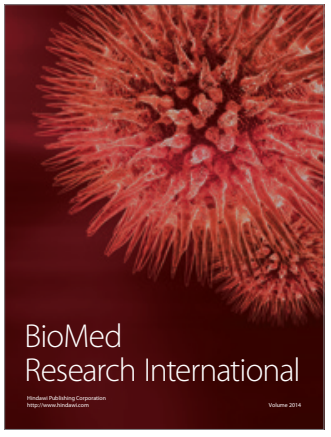

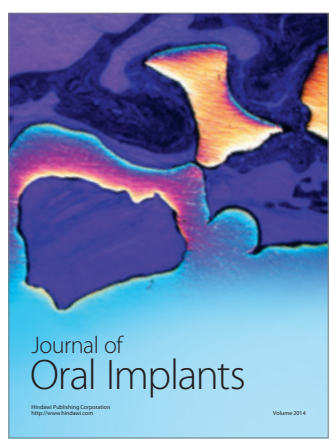
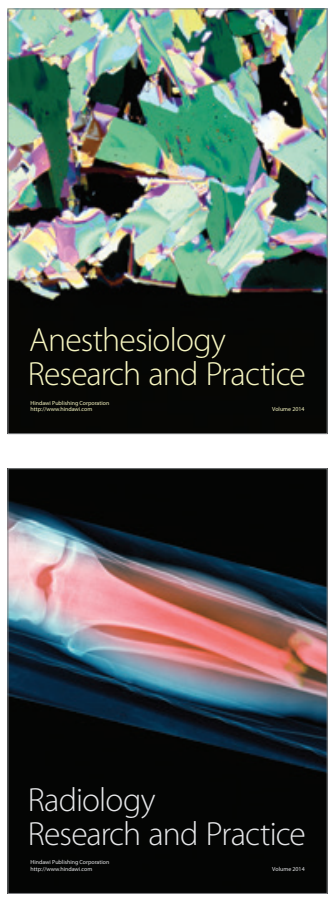